Journal of Sustainability Perspectives

journal homepage: https://ejournal2.undip.ac.id/index.php/isp/

\title{
Management of Bio-Waste by the Paper Mulch
}

\author{
Zahra Mohebi $i^{1, *}$ \\ ${ }^{1}$ Department of Natural Resources, Faculty of Agricultural Sciences \& Natural Resources, Razi University, \\ Kermanshah, Iran. \\ *corresponding author: z.mohebi@razi.ac.ir
}

\section{Article Info}

Received:

15 March 2021

Accepted:

25 May 2021

Published:

1 August 2021

DOI:

\begin{abstract}
Mulch is a type of protective covering placed on or spread over the soil surface that helps to conserve soil moisture, suppress weed growth and enrich the soil. The paper mulch is the most complete mulch and has numerous beneficial effects upon the soil and plants. This mulch which is produced from office waste paper, newspaper and wrapping papers, conserves soil moisture, is effective at suppressing and inhibiting weed growth, enhances agro-ecosystem health by improving the air and water movement through the soil; providing moist conditions thereby promoting micro-organisms and worm populations; promoting plant growth and product, promoting leaf litter build up and helping to improve the $\mathrm{pH}$ balance in the soil.
\end{abstract}

\section{Keyword:}

The paper mulch, soil moisture, control weed, plant growth

\section{Introduction}

Waste management is already governed by a substantial body of regulation in the world but there remain opportunities for further improving the management of some major waste streams. Bio-waste is defined as biodegradable park waste, food and kitchen waste, restaurants, universities, retail premises, and comparable waste from plants. Reusing biowastes has the numerous environmental and economic benefits including reduction the cost of collection (separately or with mixed waste), anaerobic digestion and composting, incineration, landfilling and their return to the energy and production cycle [1].

The waste papers as bio-waste can have a variety of uses. Paper mulch is one of their applications. This mulch is produced from office waste paper, newspaper, wrapping papers and a proportion of Kraft paper. Mulch helps to conserve soil moisture, suppress weed growth and enrich the soil by supplying elements essential for plant growth $[1,2,3$,]. One of the purposes of mulch is to create a physical barrier to protect the soil against wind and water erosion and extremes in soil temperature $[3,4]$. Also, helps to prevent soil splashing onto crops, which decreases the incidence of disease and reduces the need for washing the 
crop.

The paper mulch is the world's most complete mulch and has numerous beneficial effects upon the soil and plants. Massey University Research Results showed that the paper mulch decomposed when buried beneath the soil at a depth of $9 \mathrm{~cm}$. Samples from the buried treatment were only measured for 3 months. At this point the product became too decomposed to weigh - more than $55 \%$ of the mat had fully degraded within 90 days, with the remaining mat expected to degrade at an even faster rate. Earthworm specimens were found moving freely beneath the surface mulch and around the buried mulch in the soil. Earthworms had begun to move through the buried mulch by the second month and were found throughout this mulch after the third month [5]. Also, no detrimental effects on the soil have been observed through the use of office paper mulch [6]. In one experiment continuous use of paper mulch over four years had no detrimental affects on soil or plant growth. This mulch was ploughed into the soil at the finish of each crop.

\section{The paper mulch attributes}

\subsection{Water conservation}

Predictions have been made that unless it stabilises at between $8.5 \mathrm{~b}$ and $10 \mathrm{~b}$ by 2050 , all available arable land will be dedicated to producing food of plant origin. This in turn will bring enormous pressure on the world's available water of which only $70 \%$ is available for use and of that $70 \%, 65 \%$ is used in agriculture, $22 \%$ by industry and only $7 \%$ remains for households [7].

The paper mulch conserves soil moisture by reducing the evaporation of water from the soil by wind and sun. Air movement (wind velocity) is reduced to nil at the soil surface. Soil moisture moves by capillary action to the surface and considerable losses may occur if the soil surface is not covered by a mulch $[8,9]$.

Table 1. Conservation soil moisture profile to a soil depth of $20 \mathrm{~cm}$ by paper mulch (Southern Cross University Research Results) [10]

\begin{tabular}{llll}
\hline & Soil depth $(\mathbf{c m})$ & $\begin{array}{l}\text { Soil moisture } \\
(\%)\end{array}$ & $\%$ Increase \\
\hline Bare soil & surface & 17 & - \\
& 2 & 17 & - \\
& 5 & 29 & - \\
& 10 & 40 & - \\
\hline The paper & 20 & 42 & - \\
mulch & surface & 24 & $+\% 41$ \\
& 2 & 31 & $+\% 82$ \\
& 5 & 40 & $+\% 38$ \\
& 10 & 40 & No change \\
& 20 & 42 & No change \\
\hline
\end{tabular}

\subsection{Weed control and herbicide reduction}

Mulches have been used for many years to prevent weeds from establishing in crops by covering the soil with a material that blocks light from weed seeds, resulting in them remaining dormant [10]. The paper mulch is exceptionally effective at suppressing and inhibiting weed growth, thereby reducing weeding and digging activity. Also, it stops light 
reaching the soil thereby preventing photosynthesis and is rated as a weed stop.

In a research the paper mulch was compared with residual herbicides, black weed mat and another paper mulch for controlling weeds under trees planted in spring. Both types of paper mulch were provided weed control for about 6 months after being laid [12].

Table 2. Weed control and crop yield for lettuce and cabbage crops planted in May 2003 under mulch treatments or bare ground. Means within rows sharing the same letters are not significantly different $(P<0.05)$ [12].

\begin{tabular}{llll}
\hline & $\begin{array}{l}\text { The paper } \\
\text { mulch }\end{array}$ & $\begin{array}{l}\text { Black } \\
\text { polythene }\end{array}$ & Bare soil \\
\hline $\begin{array}{l}\text { No. weeds/m2 } \\
\text { after } 6 \text { weeks }\end{array}$ & $9.7 \mathrm{a}$ & $20.8 \mathrm{~b}$ & $761.0 \mathrm{c}$ \\
$\begin{array}{l}\text { Weed DW (g/m2) } \\
\text { after } 19 \text { weeks }\end{array}$ & $2.1 \mathrm{a}$ & $5.9 \mathrm{a}$ & $280.3 \mathrm{~b}$ \\
$\begin{array}{l}\text { Lettuce FW } \\
\text { (g/plant) after 23 }\end{array}$ & $480 \mathrm{~b}$ & $550 \mathrm{~b}$ & $170 \mathrm{a}$ \\
$\begin{array}{l}\text { weeks } \\
\text { Cabbage FW } \\
\text { (g/plant) after 25 }\end{array}$ & $1170 \mathrm{~b}$ & $1120 \mathrm{~b}$ & $560 \mathrm{a}$ \\
weeks & & & \\
\hline
\end{tabular}

\subsection{Promotes plant growth and product}

The paper mulch provides moist conditions beneath the mat promoting microorganisms and worm populations, thus promoting stronger plant and crop growth rates. The $\mathrm{pH}$ balance of the soil is also improved. The paper mulch also provides for better temperature stability in hot and cold conditions, reducing the risk of stress to new plantings $[10,11,12]$.

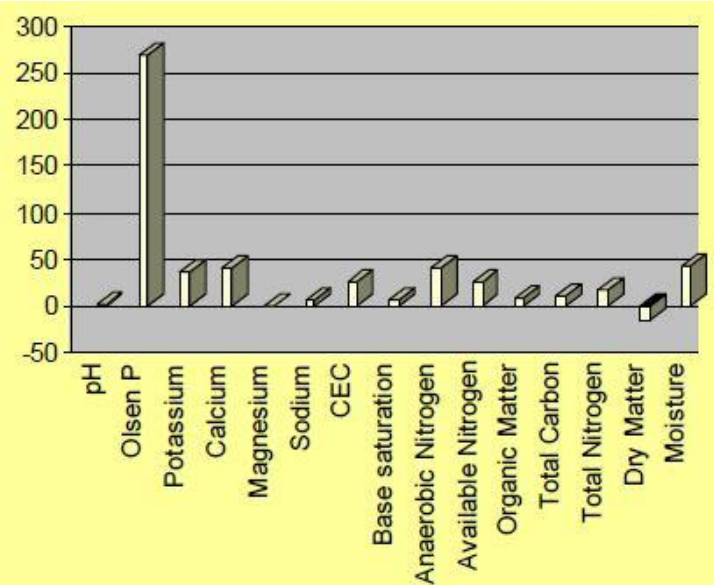

Figure 1. Percentage improvement in soil, post biodegradation of the paper mulch ( Hills Laboratories, New Zealand) [12]

Statistical analysis of the Casuarina seedling stem growth was conducted using the SPSS computer package. Mean changes in stem diameter between the first and fifth measurement of time and the first and sixth measurement of time for each treatment were measured [9]. 
Table 3. Mean Changes in Stem Diameter between bare soil and the paper mulch

Mean change in diam. Mean change in diam.

between time $1 \& 5 \quad$ between time $1 \& 6$

$\begin{array}{cll}\text { Control - bare soil } & 3.72 & 4.19 \\ \text { The paper mulch } & 4.22 & 5.3 \\ & \text { Increase of }+13.44 \% & \text { Increase of }+20.05 \%\end{array}$

Average crop weights recorded for each treatment at harvest show heaviest weights were recorded for crops grown under paper mulch and black plastic mulch treatments. Bare soil treatments resulted in low plant weights when compared to mulch treatments. The paper mulch provided greater plant fresh weights and faster crop maturity compared to unmulched treatments. Improved head formation was also observed. In addition, the paper mulch improved crop growth and reduced time to maturity. The effect of two mulch treatments compared to bare soil on crop yield for lettuce and cabbage crops planted (table 2).

\subsection{Reduces and conserves soil temperature}

The paper mulch can significantly reduce soil temperature, an important product attribute for soil and plant health in warm climates. Polythene is frequently used as a soil sterilising agent, absorbing heat from the sun and effectively burning the soil with very high temperature. For specific outcomes such as sterilising the soil, this is an admirable use for polythene however in a planting situation where polythene is used as a weed inhibitor, the adverse effect of high temperatures will sour the soil, kill the microbes and worms close to the soil surface and evaporate off any retained moisture. The paper mulch moderates soil temperature, keeping the soil healthy and thus providing a perfect environment for plant growth [9].

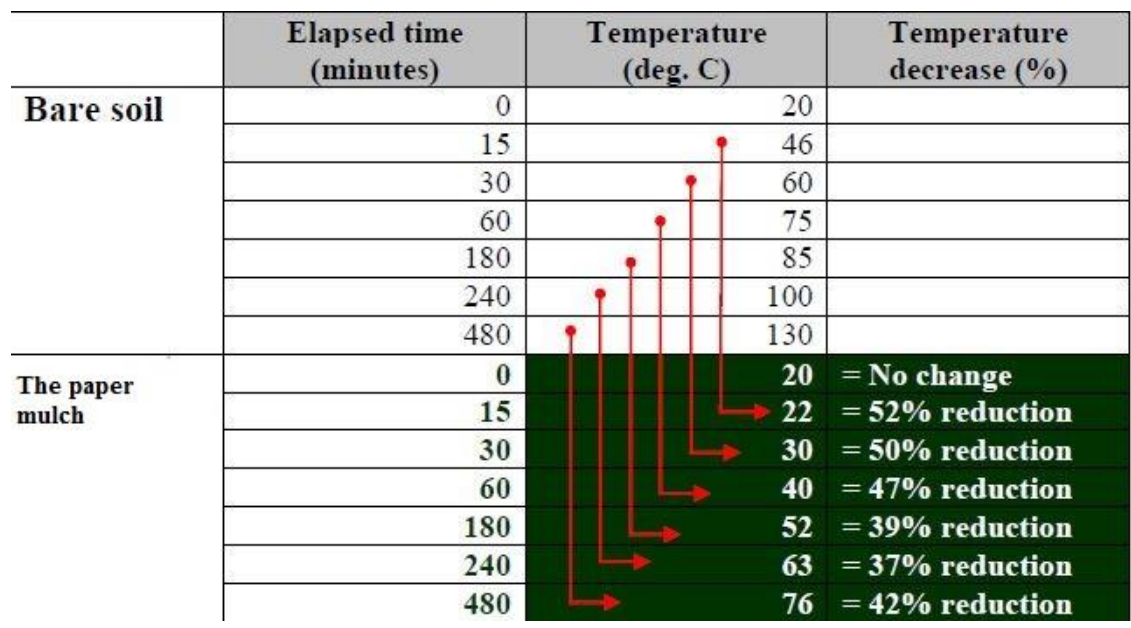

\subsection{Erosion control}

The paper mulch helps to prevent the soil becoming dry and crusty and less permeable to water penetration. Water droplets lose their velocity and cannot therefore puddle and pan soil surfaces to produce a thin cement like surface crust upon drying, a common fault of bare soil surfaces that contain clays. The irregular fibres of the lower surface of the paper mulch actually mesh (over time) with the topsoil surface thereby 
physically preventing crusting. This greatly increases surface porosity, allowing for rapid entry of water and completely eliminating run-off problems on sloping ground. Seed mats will assist in further stabilizing batters and faces. Once saturated, the paper mulch absorbs and spreads evenly further water at a rate accepted by the contact between the mat and the soil, with any surplus being shed. This minimises excess water build up under the mat and the forming of rivulets in the soil leading to soil erosion and/or soil loss [14].

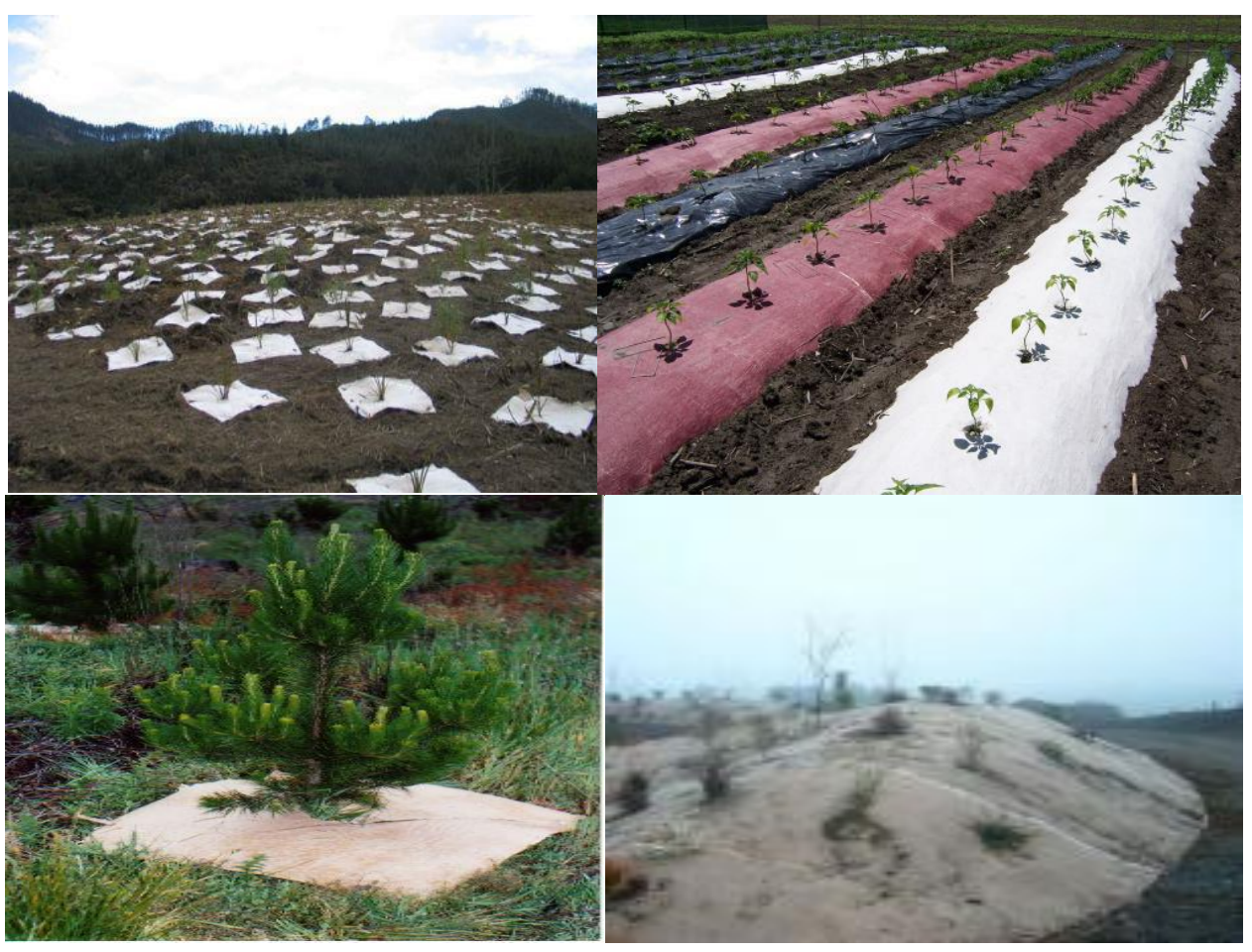

Figure 2. Pictures of the paper mulch

\section{Production and implementation of the paper mulch for the first time in}

\section{Iran}

Evaluating impact of the paper mulch on water consumption, soil properties and weed population is being implemented for the first time in the Razi University of Kermanshah. This project is supported by the University Green Management.

Pictures of the project are shown below:

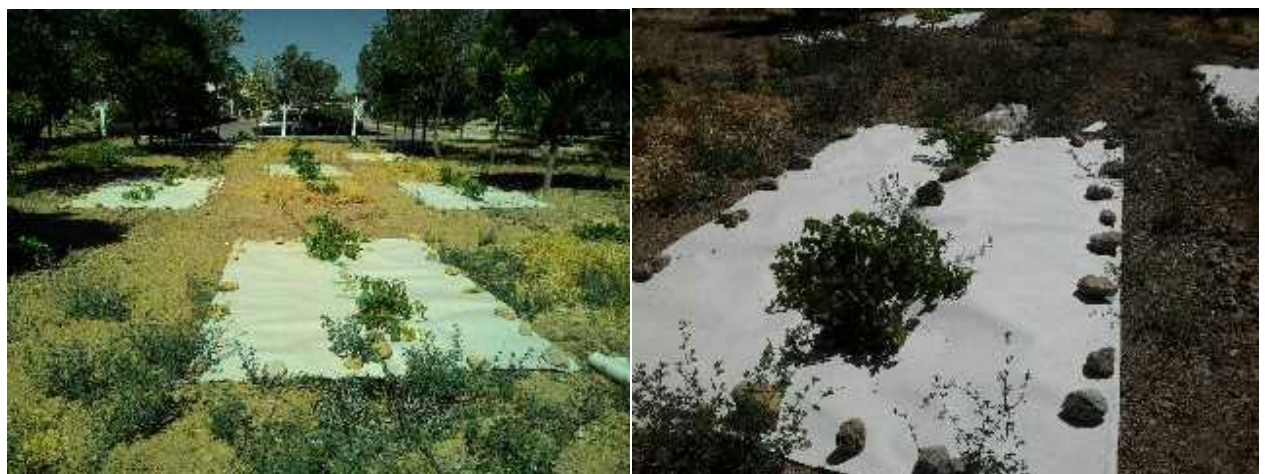

Figure 3. Implementation of paper mulch project in Razi University, Kermanshah, Iran 


\section{Conclusion}

It is increasingly recognized the world's resources are finite, and that they need to be managed and used more carefully. Paper products have a vital role in many of society's activities and basic needs. The recycling of used paper is seen as a practical way of reducing waste disposal problems (landfills) and it is seen as both economically and environmentally sensible. Simple and practical solution of the paper mulch can be done in many organizations and communities and it is a way to use of bio-wastes efficiently.

\section{References}

1. European Union Commission, 2008. Green paper on the management of bio-waste in the European Union. Brussels, Belgium.

2. Chaney, R. using newsprint as mulch. USDA-ARS environmental research laboratory in Beltsville, Maryland, USA. [Online] http://bowlingreen.ky.net/DailyNews/mulch.

3. Black, R.J., Gilman, E.F., Knox, G.W., Ruppert, K.C, 1994. Mulches for the Landscape. University of Florida. Florida Cooperative Extension Service. Fact Sheet ENH 103. March 1994

4. Munn, D.A., 1992. Comparisons of shredded newspaper and wheat straw as crop mulches. HortTechnology, 2(3), pp.361-366.

5. Hills Laboratories, New Zealand, 2006. Leachate soil analysis of biodegraded fertilised enriched mat compared with adjacent bare soil plots.

6. Johnston, L.M. 1997. The efficacy of mulch mat as a biodegradable paper mulch. Faculty of Resource Science and Management, Southern Cross University, NSW, Australia

7. Bradshaw, K., 1998. What are some strategies for dealing with first year trees in drought conditions? New Zealand Tree Grower. November 1998. 34-35.

8. Foo, C.L., Harrington, K.C. and MacKay, M.B., 2010. Comparison of weed control techniques to establish three ground cover species. New Zealand Plant Protection, 63, pp.96-101.

9. L.M. Johnston., 1997. The efficacy of mulch mat as a biodegradable paper mulch. Faculty of Resource Science and Management, Southern Cross University, NSW, Australia.

10. Morgan, W.C. 1989: Alternatives to herbicides. Plant Prot. Quart. 4: 33-37.

11. Morton, A.R. and Cameron E.A. 2006. EcoCover Paper Mulch: A Viable Alternative For Vegetable Growers. Institute of Natural Resources, Massey University, Palmerston North.

12. Harrington, K.C. and Bedford, T.A., 2004. Control of weeds by paper mulch in vegetables and trees. New Zealand Plant Protection, 57, pp.37-40.

13. Hills Laboratories, New Zealand. Leachate soil analysis of biodegraded fertilised enriched mat compared with adjacent bare soil plots.

14. Porter, D. n.d., Are mulches a good idea? West Virginia Farming and Forestry Bulletin, West Virginia, USA 